\title{
Evaluation of Fresh and Hardened Properties of Self-Compacting Concrete
}

\author{
Oladipupo S. Olafusi*, Adekunle P. Adewuyi, Abiodun I. Otunla, Adewale O. Babalola \\ Department of Civil Engineering, College of Engineering, Federal University of Agriculture, Abeokuta, Nigeria \\ Email: ${ }^{*}$ olafusidipo@yahoo.com
}

Received 2 January 2015; accepted 20 January 2015; published 22 January 2015

Copyright (C) 2015 by authors and Scientific Research Publishing Inc.

This work is licensed under the Creative Commons Attribution International License (CC BY). http://creativecommons.org/licenses/by/4.0/

(c) (i) Open Access

\section{Abstract}

This paper compared the rheological properties and compressive strengths of self-compacting concrete (SCC) and conventional cement concrete. The flowability and segregation resistance of freshly mixed concrete specimens were examined by the V-funnel apparatus, while the characteristics of passing ability were investigated with the L-box apparatus. Cylindrical concrete specimens of $100 \mathrm{~mm}$ diameter $\times 200 \mathrm{~mm}$ length were investigated for compressive strength. The rheological properties of SCC are incomparable with those of the conventional concrete due to their diverse testing methods and characteristics of individual flow. The compressive strength results of hardened concrete showed that SCC gained strength slowly compared to the conventional cement concrete due to the presence of admixtures and its 28 days strength was lower than conventional cement concrete, but SCC eventually had potentials of higher strength beyond 90 days. Finally, the effect of water-cement ratio on the plastic properties of self-compacting concrete was quite negligible compared to conventional concrete.

\section{Keywords}

Concrete, Self-Compacting Concrete, V-Funnel, L-Box, Density, Compressive Strength

\section{Introduction}

Concrete is the most versatile heterogeneous construction material and the impetus of infrastructural development of any nation. Civil engineering practice and construction works around the world depend to a very large extent on concrete [1]. It is the world's most widely used construction materials because of its properties. Self compacting concrete (SCC) was thus developed to increase concrete usage by engineers in Japan in the early 1980s with the introduction of conventional super-plasticizers to create highly fluid concrete, while also using

\footnotetext{
*Corresponding author.
}

How to cite this paper: Olafusi, O.S., Adewuyi, A.P., Otunla, A.I. and Babalola, A.O. (2015) Evaluation of Fresh and Hardened Properties of Self-Compacting Concrete. Open Journal of Civil Engineering, 5, 1-7. 
viscosity-modifying admixtures (VMA), which increased plastic viscosity thus preventing segregation up to a level of fluidity that would normally cause segregation [2]-[7].

Self-compacting concrete or self-consolidating concrete (SCC) is a highly flowable, non-segregating concrete that can spread into place, fill the formwork, and encapsulate the reinforcement without any mechanical consolidation [8]-[10]. When large quantity of heavy reinforcement is to be cast in a reinforced concrete member, it is difficult to ensure that the formwork gets completely filled with concrete. Thus, fully consolidation without voids or honeycombs through compaction by manual or mechanical vibrators is very impractical in this situation, it generates delays and additional cost in the projects and hence, the development of SCC.

The dosage of the superplasticizer and viscosity modifying admixtures (VMA) is an important parameter; which influences the rheological properties of SCC. Many research works carried out in this area have proved that the role of chemical admixtures is inevitable in achieving good rheological properties of SCC [11]-[13]. SCC thus obtained is dense, homogeneous and has a superior surface finish [10] [14] [15]. The utilization of organic or waste materials as replacements for Portland cement in SCC, such as the works of [2] [6] [7] [13] [16]-[23] have been reported to significantly enhance the rheology and strength properties of SCC. It also reduces the high cost of SCC production per cubic meter, which has greatly influenced its use in developing nations. One of the biggest differences between SCC and usual concrete is their incorporation of materials. SCC is considered to be a concrete that can be placed and compacted with no vibration and segregation. Cement which is the most important part of the concrete is very expensive; hence, the use of SCC makes it more economical [19]. Therefore, the purpose of this research is to investigate the rheological properties and compressive strengths of SCC compared with conventional cement concrete.

\section{Materials and Methods}

\subsection{Materials}

Ordinary Portland cement (32.5 grade), fine (sharp river sand), coarse aggregate (20 - $25 \mathrm{~mm}$ granite stones) and Conplast SP430 Superplasticizers (a chloride free, super plasticising admixture based on selected sulphonated naphthalene polymers) were used in this research. Previous research studies showed that superplasticizer can be used to achieve good workability. The high flowability is achieved by using superplasticizer, while segregation resistance was either achieved by using large quantity of fine materials or appropriate VMA [24]-[28].

\subsection{Mix Proportions and Curing}

Two series of SCC mixes were compared with a conventional concrete as control mix to study the plastic and compressive strength properties. A water-to-cement ratio (w/c) of 0.5 was used for the control mix, while it was varied at 0.5 and 0.38 for the SCC mixes. Conplast SP430 Superplasticizers (a chloride free, super plasticising admixture based on selected sulphonated naphthalene polymers) was used to maintain high workability. The specimens were demoulded and cured in water until the test age. The mix proportions are given in Table 1.

\subsection{Rheological Properties Test}

Passing ability of the mixes was examined by the L-box apparatus while their flowability and segregation resistance were examined by the V-funnel apparatus.

\subsection{Compressive Strength Test}

Cylindrical concrete specimens of $100 \mathrm{~mm}$ diameter $\times 200 \mathrm{~mm}$ length were investigated for compressive strength at ages 7, 14, 21, 28 and 90 days. The compressive strength test was carried out as per ASTM C39 [29]. The reported results are the average of three samples [28]-[31].

\section{Results and Discussion}

\subsection{Rheological Properties Test}

Figure 1 shows a "foamy" chemical reaction of the superplasticizers on the SCC mix, which makes slump test unsuitable for the mix as the SCC mix had a total collapse when the slump cone was removed. Figure 2 shows 
the L-box apparatus which tested the passing ability of SCC [30] [31] by measuring the ratio of the difference between the beginning and end of the box, while Figure 3 shows the V-funnel tests for the filling ability and segregation resistance of the SCC mixes [30] [31]. The results of the rheological properties are presented on Table 2 which revealed acceptable values for the passing ability, filling ability and segregation resistance of the SCC mixes [7] [9] [10] [14] [31]. The graphical illustration is also presented on Figure 4.

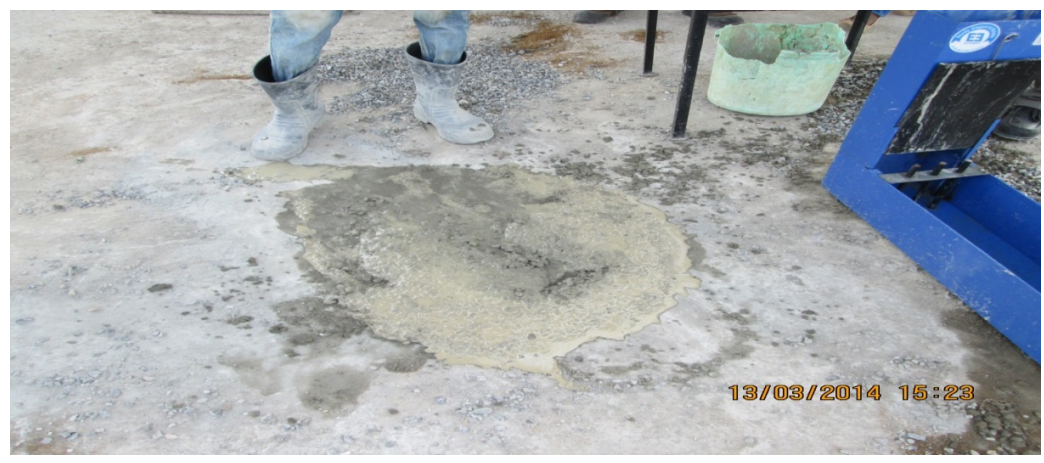

Figure 1. Reactive mix of SCC.

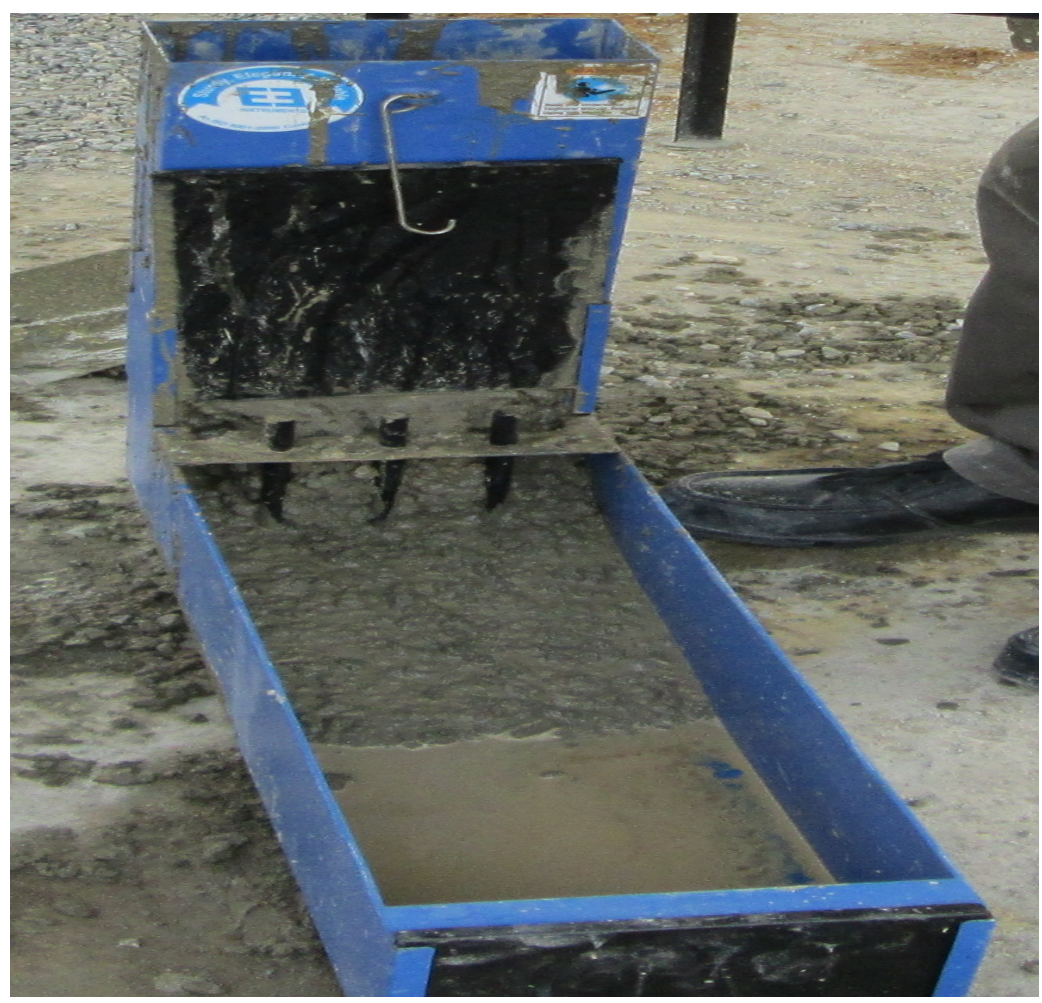

Figure 2. L-box test.

Table 1. Mix proportion.

\begin{tabular}{cccccc}
\hline Sample & w/c & $\begin{array}{c}\text { Cement content } \\
\left(\mathrm{kg} / \mathrm{m}^{3}\right)\end{array}$ & $\begin{array}{c}\text { Fine } \\
\text { aggregate }\left(\mathrm{kg} / \mathrm{m}^{3}\right)\end{array}$ & $\begin{array}{c}\text { Coarse aggregate } \\
\left(\mathrm{kg} / \mathrm{m}^{3}\right)\end{array}$ & $\begin{array}{c}\text { Admixture } \\
(\text { litres } / 100 \mathrm{~kg} \text { of cement })\end{array}$ \\
Control & 0.5 & 375 & 750 & 1500 & - \\
SCC-1 & 0.5 & 375 & 890 & 875 & 2 \\
SCC-2 & 0.38 & 375 & 890 & 875 & 2 \\
\hline
\end{tabular}


Table 2. Results of rheological properties.

\begin{tabular}{ccccc}
\hline Sample & Slump $(\mathrm{cm})$ & Flowability $(\mathrm{sec})$ & Segregation resistance $(\mathrm{sec})$ & Passing ability $\left(\mathrm{h}_{2} / \mathrm{h}_{1}\right)$ \\
\hline Control & 15.0 & - & - & - \\
SCC-1 & 0.0 & 10 & 11 & 0.8 \\
SCC-2 & 0.0 & 10 & 14 & 0.9 \\
\hline
\end{tabular}

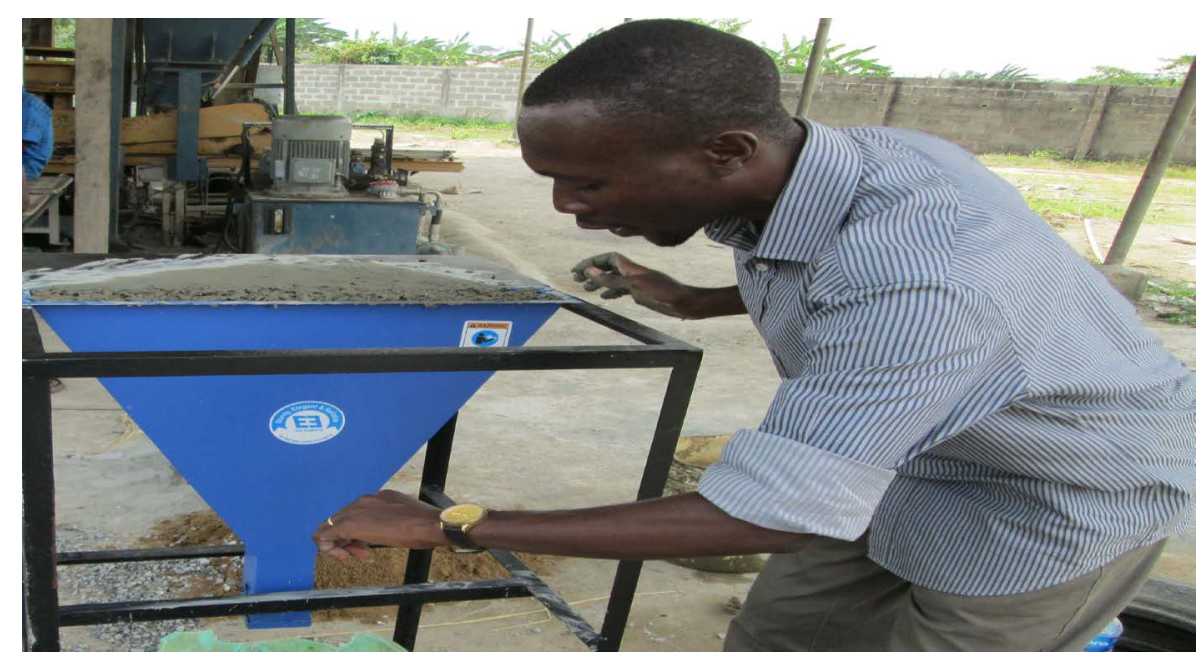

Figure 3. V-funnel test.

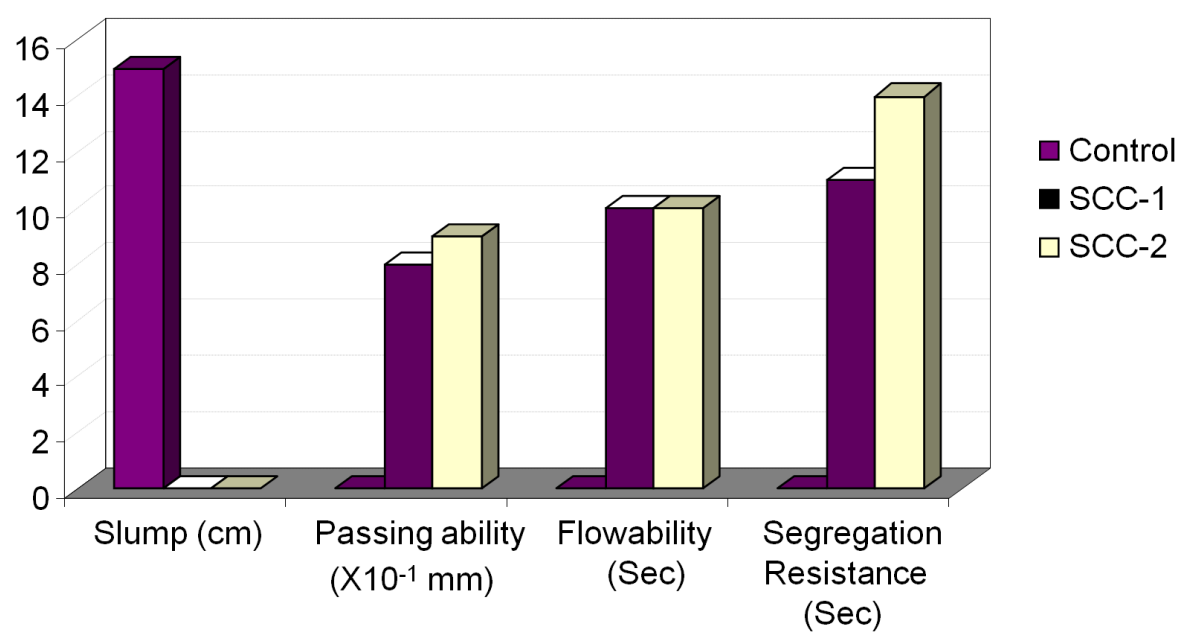

Figure 4. Rheological (plastic) properties.

\subsection{Hardened Concrete Properties}

The average densities and compressive strengths of SCC and conventional concrete (Control) specimens are presented in Table 3 and Table 4 respectively; while their graphical illustrations are presented in Figure 5 and Figure 6 respectively. The same mean density of $2500 \mathrm{~kg} / \mathrm{m}^{3}$ was obtained for the control and SCC-2 mixes, while that of SCC-1 was $2510 \mathrm{~kg} / \mathrm{m}^{3}$ at 28 days which fell within the specified range of $2200-2600 \mathrm{~kg} / \mathrm{m}^{3}$ for the densities of normal weight concrete [32]. Hence, the concrete samples are designated as normal weight concrete.

The compressive strengths of both SCC and conventional concrete developed continuously, but the rate of strength gain in the SCC mixes was slower than the conventional concrete until after 28 days; while the SCC-2 


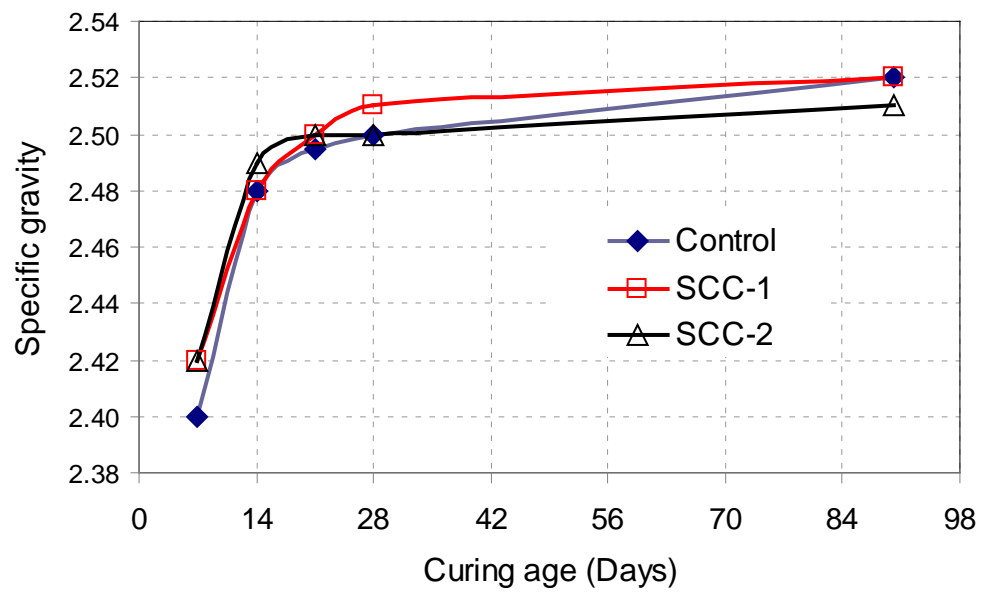

Figure 5. Specific gravity-curing age relationship of concrete specimens.

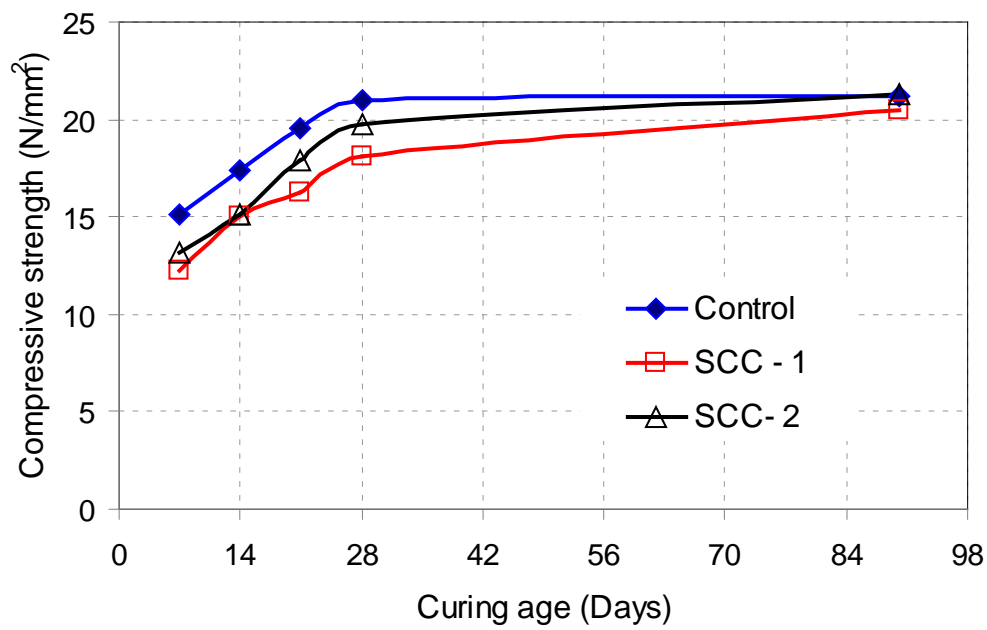

Figure 6. Compressive strength-age relationship (N/mm²).

Table 3. Densities of hardened concrete specimens.

\begin{tabular}{rccccc}
\hline \multirow{2}{*}{ Sample } & \multicolumn{5}{c}{ Average density $\left(\times 1000 \mathrm{~kg} / \mathrm{m}^{3}\right)$ for different curing ages } \\
\cline { 2 - 6 } & 7 days & 14 days & 21 days & 28 days & 90 days \\
\hline Control & 2.40 & 2.48 & 2.48 & 2.50 & 2.52 \\
SCC-1 & 2.42 & 2.48 & 2.50 & 2.51 & 2.52 \\
SCC-2 & 2.42 & 2.49 & 2.50 & 2.50 & 2.51 \\
\hline
\end{tabular}

Table 4. Compressive strength of hardened concrete cylinder specimens.

\begin{tabular}{rccccc}
\hline \multirow{2}{*}{ Sample } & \multicolumn{5}{c}{ Compressive strength $\left(\mathrm{N} / \mathrm{mm}^{2}\right)$ for different curing ages } \\
\cline { 2 - 5 } & 7 days & 14 days & 21 days & 28 days & 90 days \\
\hline Control & 15.08 & 17.39 & 19.52 & 20.98 & 21.21 \\
SCC-1 & 12.28 & 14.97 & 16.23 & 18.15 & 20.50 \\
SCC-2 & 13.22 & 15.13 & 17.88 & 19.76 & 21.33 \\
\hline
\end{tabular}


had 90 days compressive strength of $21.33 \mathrm{~N} / \mathrm{mm}^{2}$ which was about $1 \%$ greater than each of the control sample of $21.21 \mathrm{~N} / \mathrm{mm}^{2}$ and the SCC- 1 of $20.50 \mathrm{~N} / \mathrm{mm}^{2}$. This implies that SCC has the potentials of greater compressive strengths than the conventional cement concrete after 28 days when properly mixed and cured. However, the hardened concrete examination indicated that water-cement ratio also influences the density and strength properties of SCC.

\section{Conclusions}

Based on the findings, the comparative assessment of conventional and self-compacting concrete, the following conclusions are drawn.

1) Rheological properties of conventional and self-compacting concrete are quite different.

2) Water-cement ratio influences the strength properties of self-compacting concrete as much as it does in conventional concrete, but its effect on the plastic properties of self-compacting concrete is almost negligible compared with conventional concrete.

3) The compressive strength of a well designed SCC mix at 28 days is in the range of $85 \%-95 \%$ of conventional concrete, but shows a potential of greater compressive strength at 90 days and beyond.

\section{References}

[1] Olafusi, O.S. and Olutoge, F.A. (2012) Strength Properties of Corn Cob Ash Concrete. Journal of Emerging Trends in Engineering and Applied Sciences (JETEAS), 3, 297-301.

[2] Liu, M. (2010) Self-Compacting Concrete with Different Levels of Pulverized Fuel Ash. Construction and Building Materials, 24, 1245-1252. http://dx.doi.org/10.1016/j.conbuildmat.2009.12.012

[3] Leemann, A., Loser, R. and Munch, B. (2010) Influence of Cement Type on Its Porosity and Chloride Resistance of Self-Compacting Concrete. Cement and Concrete Composites, 32, 116-120. http://dx.doi.org/10.1016/j.cemconcomp.2009.11.007

[4] Kou, S.C. and Poon, C.S. (2009) Properties of Self-Compacting Concrete Prepared with Coarse and Fine Recycled Concrete Aggregates. Cement and Concrete Composites, 31, 622-627. http://dx.doi.org/10.1016/j.cemconcomp.2009.06.005

[5] Filho, F.M.A., Barrag'an, B.E., Casas, J.R. and ElDebs, A.L.H.C. (2010) Hardened Properties of Self-Compacting Concrete-A Statistical Approach. Construction and Building Materials, 24, 1608-1615. http://dx.doi.org/10.1016/j.conbuildmat.2010.02.032

[6] Boukendakdji, O., Kenai, S., Kadri, E.H. and Rouis, F. (2009) Effect of Slag on the Rheology of Fresh Self-Compacted Concrete. Construction and Building Materials, 23, 2593-2598. http://dx.doi.org/10.1016/j.conbuildmat.2009.02.029

[7] Craeye, B., Schutter, D.G., Desmet, B., et al. (2010) Effect of Mineral Filler Type on Autogenous Shrinkage of SelfCompacting Concrete. Cement and Concrete Research, 40, 908-913. http://dx.doi.org/10.1016/j.cemconres.2010.01.014

[8] ACI Committee 237 (2005) Self-Consolidating Concrete. Emerging Technology Document, American Concrete Institute, Farmington Hills.

[9] Bartos, P. (1993) Self-Compacting Concrete. Concrete, 33, 9-14.

[10] Okamura, H.M. and Ouchi, M. (2003) Self-Compacting Concrete. Journal of Advances Concrete Technology, 1, 5-15. http://dx.doi.org/10.3151/jact.1.5

[11] Li, B., Wang, J. and Zhou, M. (2009) Effect of Limestone Fines Content in Manufactured Sand on Durability of Lowand High-Strength Concretes. Construction and Building Materials, 23, 2846-2850. http://dx.doi.org/10.1016/j.conbuildmat.2009.02.033

[12] Corinaldesi, V. and Moriconi, G. (2009) Influence of Mineral Additions on the Performance of 100\% Recycled Aggregate Concrete. Construction and Building Materials, 23, 2869-2876. http://dx.doi.org/10.1016/j.conbuildmat.2009.02.004

[13] Grdić, Z., Despotović, I. and Ćurčić, G.T. (2008) Properties of Self-Compacting Concrete with Different Type of Additives. Facta Universitatis, 6, 173-177.

[14] EFNARC (2002) Specification and Guidelines for Self-Compacting Concrete. Farnham.

[15] de Larrard, F., Ferraris, C.F. and Sedran, T. (1996) Fresh Concrete: A Herschel-Bulkley Material. Materials and Structures, 31, 494-498.

[16] Adewuyi, A.P. and Ola, B.F. (2005) Application of Waterworks Sludge as Partial Replacement for Cement in Concrete 
Production. Science Focus Journal, 10, 123-130.

[17] Adewuyi, A.P. and Adegoke, T. (2008) Exploratory Study of Periwinkle Shells as Coarse Aggregates in Concrete Works. Journal of Engineering and Applied Sciences, 3, 1-5.

[18] Rukzon, S. and Chindaprasirt, P. (2014) Use of Rice Husk-Bark Ash in Producing Self-Compacting Concrete. Advances in Civil Engineering, 2014, Article ID: 429727.

[19] Heidari, A. and Zabihi, M. (2014) Self-Compacting Concrete Incorporating Micro-SiO ${ }_{2}$ and Acrylic Polymer. Advances in Civil Engineering, 2014, Article ID: 652362.

[20] Elinwa, A.U. and Mamuda, A.M. (2014) Sawdust Ash as Powder Material for Self-Compacting Concrete Containing Naphthalene Sulfonate. Advances in Civil Engineering, 2014, Article ID: 129276.

[21] Nalanth, N., Venkatesan, P.V. and Ravikumar, M.S. (2014) Evaluation of the Fresh and Hardened Properties of Steel Fibre Reinforced Self-Compacting Concrete Using Recycled Aggregates as a Replacement Material. Advances in Civil Engineering, 2014, Article ID: 671547.

[22] Fathi, A., Shafiq, N., Nuruddin, M.F. and Elheber, A. (2013) Study the Effectiveness of the Different Pozzolanic Material on Self-Compacting Concrete. ARPN Journal of Engineering and Applied Sciences, 8, 299-305.

[23] Safiuddin, M., West, J.S. and Soudki, K.A. (2012) Properties of Freshly Mixed Self-Consolidating Concretes Incorporating Rice Husk Ash as a Supplementary Cementitious Material. Construction and Building Materials, 30, 833-842. http://dx.doi.org/10.1016/j.conbuildmat.2011.12.066

[24] Geiker, M.R., Brandl, M., Thrane, L.N., Bager, D.H. and Wallevik, O. (2002) The Effect of Measuring Procedure on the Apparent Rheological Properties of Self-Compacting Concrete. Cement and Concrete Research, 32, 1791-1795. http://dx.doi.org/10.1016/S0008-8846(02)00869-4

[25] Schwartzentruber, L.D., le Roy, R. and Cordin, J. (2006) Rheological Behaviour of Fresh Cement Pastes Formulated from a Self Compacting Concrete (SCC). Cement and Concrete Research, 36, 1203-1213. http://dx.doi.org/10.1016/j.cemconres.2004.10.036

[26] Su, N., Hsu, K.C. and Chai, H.-W. (2001) A Simple Mix Design Method for Self-Compacting Concrete. Cement and Concrete Research, 31, 1799-1807. http://dx.doi.org/10.1016/S0008-8846(01)00566-X

[27] Nunes, S., Figueiras, H., Milheiro Oliveira, P., Coutinho, J.S. and Figueiras, J. (2006) A Methodology to Assess Robustness of SCC Mixtures. Cement and Concrete Research, 36, 2115-2122. http://dx.doi.org/10.1016/j.cemconres.2006.10.003

[28] Jin, J. (2002) Properties of Mortar for Self-Compacting Concrete. Ph.D. Thesis, University College London, London.

[29] ASTM C39 (2005) Standard Test Method for Compressive Strength of Cylindrical Concrete Specimens. Annual Book of ASTM Standards, 04.01, 21-27.

[30] EN 12350-8 (2007) Testing Fresh Concrete-Part 8: Self-Compacting Concrete-Slump-Flow Test.

[31] EN 12350-9 (2007) Testing Fresh Concrete-Part 9: Self-Compacting Concrete-V-Funnel Test.

[32] Neville, A.M. (2000) Properties of Concrete. 4th Edition, Longman, England. 
Scientific Research Publishing (SCIRP) is one of the largest Open Access journal publishers. It is currently publishing more than 200 open access, online, peer-reviewed journals covering a wide range of academic disciplines. SCIRP serves the worldwide academic communities and contributes to the progress and application of science with its publication.

Other selected journals from SCIRP are listed as below. Submit your manuscript to us via either submit@scirp.org or Online Submission Portal.
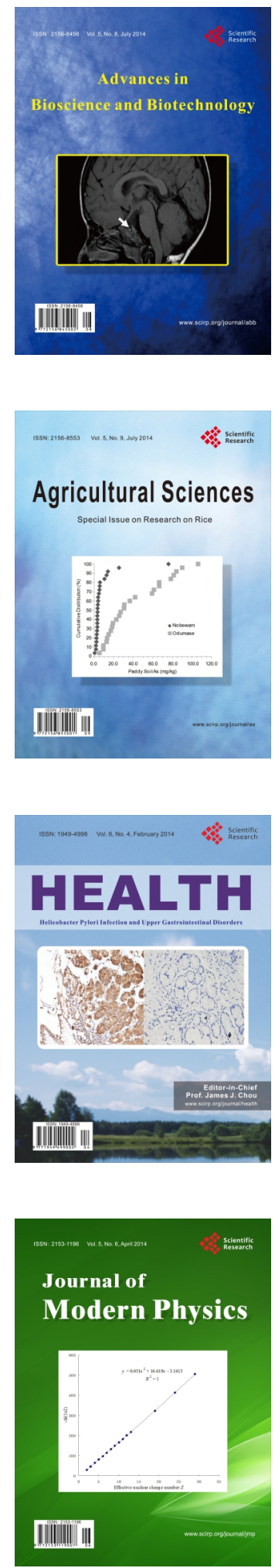
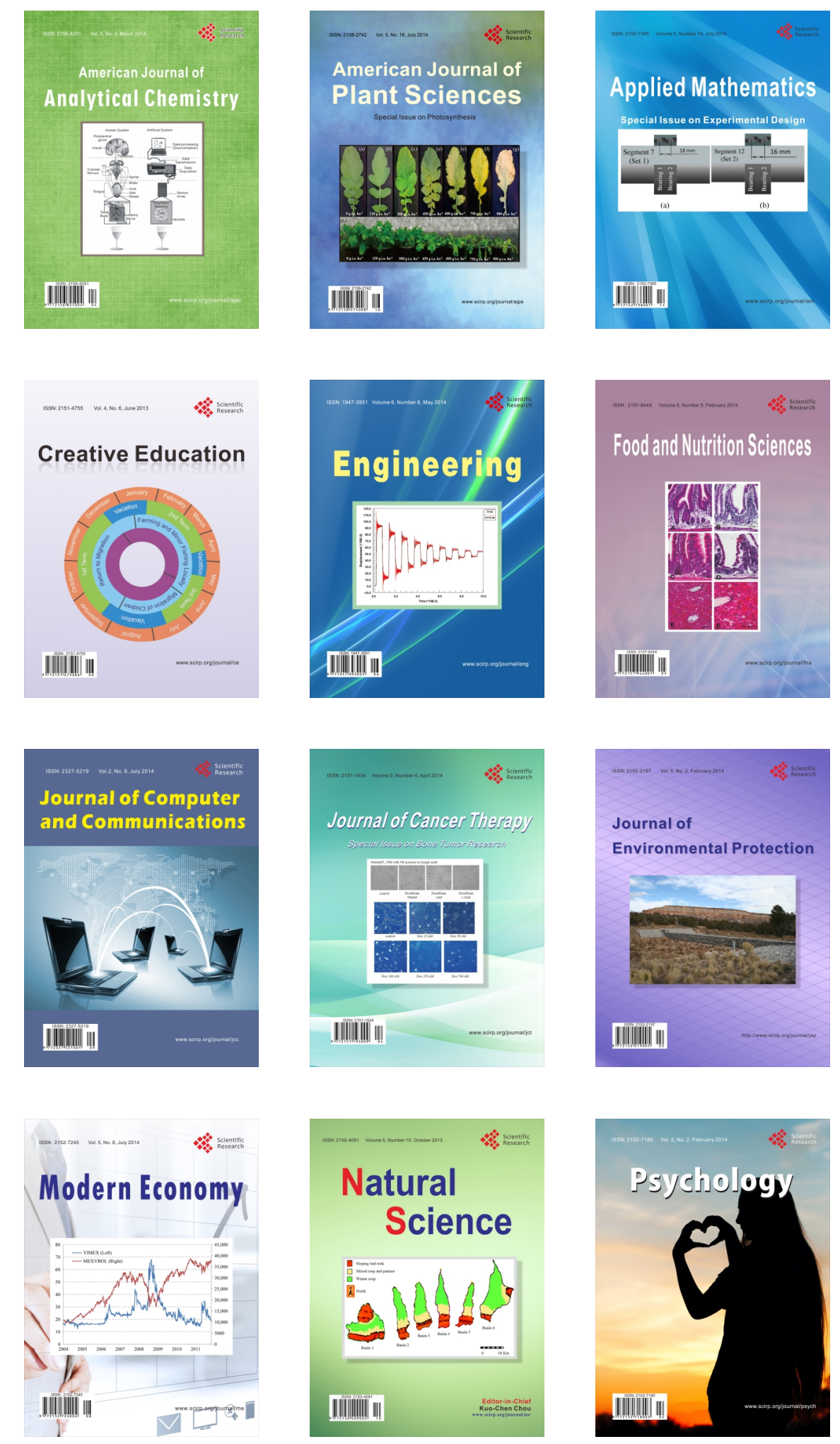